\title{
Development of novel human in vitro vascularized adipose tissue model with functional macrophages
}

\author{
Outi Huttala (1) J Jertta-Riina Sarkanen · Marika Mannerström • \\ Tarja Toimela $\cdot$ Tuula Heinonen $\cdot$ Timo Ylikomi
}

Received: 7 March 2020/Accepted: 4 June 2020/Published online: 10 June 2020

(C) The Author(s) 2020

\begin{abstract}
Inflammation has been proven significant factor in development of type 2 diabetes. So far, most of the adipose tissue related research has been performed in animals, mainly rodent models. The relevance of translation of animal results to humans is questionable. However, in vitro model with relevant human cell source, such as human adipose tissue stromal cells (hASC), can be developed and should be utilized for human adipose tissue research. We developed in vitro models of human adipose tissue utilizing hASC, endothelial cells and monocytes/macrophages. By isolating endothelial cells and macrophages from same adipose tissue as hASC, we were able to provide method for constructing personalized models of adipose tissue. With these models, we studied the effect of macrophages on adipogenesis and protein secretion, with and without vasculature. The models were analyzed for immunocytochemical markers, cell number, triglyceride accumulation and protein secretion. We found that lipid accumulation was greater in adipocytes in the presence of macrophages. Interferon gamma increased this difference between adipocyte culture and Adipocyte-
\end{abstract}

O. Huttala $\cdot$ M. Mannerström $\cdot$ T. Toimela $\cdot$ T. Heinonen FICAM, Faculty of Medicine and Health Technology, University of Tampere, Tampere, Finland

O. Huttala $(\bowtie) \cdot$ J.-R. Sarkanen · T. Ylikomi Cell Biology, Faculty of Medicine and Health Technology, University of Tampere, Tampere, Finland e-mail: Outi.huttala@tuni.fi
Macrophage co-culture. Protein secretion was affected more by macrophages when vasculature was not present compared to the mild effect when vasculature was present. The vascularized adipose model with macrophages is valuable tool for human adipose tissue research, especially for the personalized medicine approaches; for choosing the right treatments and for studying rare medical conditions.

Keywords hASC - Adipose tissue derived endothelial cells · Interferon gamma - Adipogenesis · In vitro model development - Adipose tissue derived macrophages

$\begin{array}{ll}\text { Abbreviations } \\ \text { AMM } & \text { Adipocyte-Macrophage Model } \\ \text { AMMI } & \text { Adipocyte-Macrophage Model with IFN } \gamma \\ \text { ATE } & \text { Adipose tissue extract } \\ \text { G-CSF } & \text { Granulocyte-colony stimulating factor } \\ \text { GM- } & \text { Granulocyte-macrophage colony- } \\ \text { CSF } & \text { stimulating factor } \\ \text { hASC } & \text { Human adipose stromal cells } \\ \text { HUVEC } & \text { Human umbilical vein endothelial cells } \\ \text { IFN } \gamma & \text { Interferon gamma } \\ \text { IGF } & \text { Insulin-like growth factor 1 } \\ \text { IL-1a } & \text { Interleukin 1a } \\ \text { IL-6 } & \text { Interleukin 6 } \\ \text { IL-8 } & \text { Interleukin } 8 \\ \text { IP-10 } & \text { Interferon gamma-induced protein } \\ & \text { 10/CXCL10 }\end{array}$


LDL Low density lipoprotein

PAI Plasminogen activator inhibitor 1

RT Room temperature

SFM Serum free medium

TGF $\beta$ Transforming growth factor $\beta$

TNF $\alpha \quad$ Tumor necrosis factor $\alpha$

VATMI Vascularized Adipose Tissue model with Macrophages with IFN $\gamma$

\section{Introduction}

During the recent decades, the incidence of obesity has increased dramatically throughout the world. As the prevalence of obesity increases the amount of related diseases increases. Obesity is associated with type 2 diabetes as well as cancer, sleep apnea, asthma, degenerative joint disease, hypertension, renal failure, stroke, and cardiovascular disease (Switzer et al. 2013, van Baak 2013). Hence, adipose tissue research, particularly studies of disturbances in normal tissue function, is ever more important. Adipose tissue contains heterogeneous cell population and has multiple functions including energy storage, endocrine functions and maintenance of metabolic homeostasis. Adipose tissue is composed of adipose stem cells, mature adipocytes, immune cells, fibroblasts, endothelial cells. Adipocytes are the main cell type in adipose tissue. Due to their large size, they occupy $90 \%$ of the volume of adipose tissue (Kanneganti and Dixit 2012).

Inflammation of adipose tissue has been suspected to be key reason behind many of the complications such as type 2 diabetes mellitus (the loss of insulin sensitivity). In adipose tissue, insulin resistance manifests as impaired glucose disposal and enhanced triglyceride lipolysis, resulting in hyperinsulinemia, hyperglycemia, and hyperlipidemia (Shulman 2000). Obesity leads to enlargement of adipocytes and in addition, promotes macrophage accumulation in adipose tissue (Gil et al. 2007; Murano et al. 2008). Obese people have been shown to have a continuous lowgrade inflammation in their adipose tissue (Gil et al. 2007). The first evidence of link between inflammation, obesity and insulin resistance was the finding that increased expression of tumor necrosis factor $\alpha$ $(\mathrm{TNF} \alpha)$, an inflammatory cytokine, promoted insulin resistance via serine phosphorylation of IRS1 (Hotamisligil et al. 1993, 1996).

Interferon gamma (IFN $\gamma$ ) produced by macrophages is one of the markers involved in adipose tissue inflammation. Obese IFN $\gamma$-deficient animals have been shown to have significantly reduced expression of inflammatory genes $\mathrm{TNF} \alpha$ and monocyte chemoattractant protein-1, decreased inflammatory cell accumulation, and better glucose tolerance than control animals (Rocha et al. 2008). In addition, obese IFN $\gamma$-knockouts, have demonstrated improved insulin sensitivity and decreased adipocyte size (O'Rourke et al. 2012). Adipose stem cells have been shown to inhibit the Th1 phenotype and subsequently decrease IFN $\gamma$ and TNF $\alpha$ production but also increase the secretion of IFN $\gamma$ production from Th17 cells (Eljaafari et al. 2015).

Along with inflammation, theories on the reasons leading to insulin resistance include the impaired adipogenesis (Okuno et al. 2018). The process of stem cells maturing into adipocytes is called adipogenesis. Adipogenesis would lead to formation of new adipocytes and hence relieve the stress of over expanding adipocytes. When the adipocytes overexpand the stress signals get activated (Haczeyni et al. 2018). This in turn influences the function of mitochondria and leads to the state of inflammation (Codoner-Franch et al. 2011, Patti and Corvera 2010). It is still not quite clear which event in this cascade finally causes the insulin resistant stage in adipocytes. Information of adipogenesis in the presence of inflammation and studies on the role of these numerous factors known to take part in the formation of insulin resistance would lead to the possibility of new treatment methods for obesity related diseases. Also, the role of different cells in the development of insulin resistance is still largely unknown. Personalized in vitro models with cells from only one patient could also result in even better insights of the development of these diseases.

Relevant and reliable adipose tissue research requires suitable tools to achieve high quality results. Although the natural heterogeneity of adipose tissue is achieved when using animal models, the species-tospecies variation in translating these results is too great flaw to dismiss (Seok et al. 2013). Murine models have been extensively used to identify and test drug candidates prior to clinical trials (European Commission 2010; US Department of Health and Human 
Services Food and Drug Administration, Center for Drug Evaluation and Research Guidance for Industry 2006; Woodcock and Woosley 2008). However, only few of these candidates have been successful in the human trials (Hackam and Redelmeier 2006; van der Worp et al. 2010). The success rates for those trials and animal experiments, where the studied disease involves inflammation, seem to be especially low (Mitka 2011; Seok et al. 2013). As an alternative, in vitro models have been developed. However, most in vitro models developed so far contain animal cells including 3T3-L1 adipocytes but lack all other components of adipose tissue (Ruiz-Ojeda et al. 2016). These may shed light on some aspects of adipose tissue function but are not optimal for studying human adipose tissue biology. Hence, the need for better models is evident for the research of human adipose tissue and its complications, especially inflamed adipose tissue.

Human adipose tissue is a vast and easy source of cells, which are relevant due to their human origin. Human adipose tissue stromal cells (hASC), obtained from adipose tissue, are widely used, due to their wellestablished isolation and culturing methods, plasticity, easiness to obtain and lack of ethical concerns. One great advantage for them is the ability to produce them in reproducible manner and in ways that allow clinical use (Patrikoski et al. 2013). Consequently, hASC have been utilized in many different in vitro tissue models including vasculature/angiogenesis models (Huttala et al. 2015; Merfeld-Clauss et al. 2010), adipose tissue models (Huttala et al. 2016, 2018; Volz et al. 2018) and in cartilage and bone tissue engineering (Ojansivu et al. 2015; Vuornos et al. 2016).

Here we present adipose tissue models, which combine in vitro human adipocytes (differentiated from hASC), vascularization (composed of human umbilical vein endothelial cells (HUVEC) and hASC) and human primary monocytes differentiated to macrophages. Others have developed similar human hASC-immune cell co-culture models (Eljaafari et al. 2015; Kongsuphol et al. 2019; Liu et al. 2019) but have not contained endothelial cells. Also, no other endothelial cell containing adipose tissue model including immune cells were found in literature which would utilize natural adipogenesis induction (Sarkanen et al. 2012a, b). The use of natural adipogenesis induction (Adipose Tissue Extract, ATE) is also beneficial for the vascular development compared to the commonly used chemical adipogenesis cocktail (Kang et al. 2009; Sheu et al. 2006).

Our goal was to develop versatile models which allow studying the effects of inflammation markers like IFN $\gamma$ on adipocytes, immune cells and vasculature. Also, the aim was that these models allow the studies of the interaction between adipocytes, vasculature (endothelial cells) and immune cells. In these developed models we specifically study the effect of macrophages by comparing each culture set-up to a same set-up lacking the macrophages. Finally, for the personalized medicine purposes, the developed method would allow the use of single donor adipose tissue sample (isolation the endothelial cells and macrophages from adipose tissue along with hASC). This type of protocol provides a relevant model for the needs of personalized medicine.

\section{Materials and methods}

\section{Ethical considerations}

This in vitro study conforms to the ethical principles outlined in the Declaration of Helsinki. The human adipose tissue samples and human umbilical cords were received with written informed consent from Tampere University Hospital, Tampere, Finland. The use of adipose tissue derived cells and human umbilical cord endothelial cells (HUVEC) were approved by The Regional Ethics Committee of Tampere University Hospital's Responsibility Area, Tampere, Finland with permit numbers of R15161 and R15033, respectively. The blood samples from which monocytes were isolated, were ordered from Finnish Red Cross Blood service, and used with their permit number 35/2014.

\section{Isolation and treatment of hASC, HUVEC} and monocytes

\section{Isolation and culture hASC and HUVEC}

Isolation of hASC and HUVEC is depicted in Sarkanen et al. (2012a, b). Before cryopreservation, the cells were screened for mycoplasma utilizing MycoAlert ${ }^{\circledR}$ Detection Kit (Lonza Group LTD, Basel Switzerland) and were mycoplasma free. The used batches of hASC were proven to express CD73, CD90 and CD105 (BD) 
as described previously (Huttala et al. 2015). Same cell batch of hASC (adipose tissue obtained from one patient) was utilized throughout this study. The adipose tissue sample was subcutaneous fat from abdomen of obese female who was not known to suffer from any metabolic disorder. Also, same batch of HUVEC (umbilical cord from another patient) was used throughout this study when HUVEC were utilized. hASC were propagated in hASC medium (Table 1). HUVEC were propagated in EGM-2 Endothelial Cell Growth Medium-2 (Lonza). In the models, hASC were used at passage 2 and HUVEC at passage 4 .

\section{Isolation of monocytes from human blood}

Monocytes were isolated from blood utilizing Ficoll Paque Plus (GE Health care). Blood sample diluted with PBS was added on top of Ficol and these tubes were centrifuged for $40 \mathrm{~min}$ at $400 \mathrm{G}$ without brakes. Buffy coat was collected, and PBS washes were performed three times, first centrifugation at $350 \mathrm{~g}$ for $10 \mathrm{~min}$, second at $200 \mathrm{~g}$ for $10 \mathrm{~min}$ and third at $350 \mathrm{~g}$ for $10 \mathrm{~min}$. This pellet, containing mononuclear cells from blood, was resuspended to PBS and suspension was filtered through $30 \mu \mathrm{m}$ filter (BD), centrifuged at $300 \mathrm{~g}$ for $10 \mathrm{~min}$ and supernatant was removed. To separate T cells from this cell suspension, human Pan $\mathrm{T}$ cell isolation kit (Miltenyi Biotec,

Table 1 Media utilized in the study, their content and manufacturer

\begin{tabular}{|c|c|c|}
\hline Medium name & Components & Manufacturer \\
\hline hASC medium & $\begin{array}{l}10 \% \text { Human Serum } \\
2 \mathrm{mM} \text { L-Glutamine } \\
\text { in Dulbecco's Modified Eagle's Medium Nutrient Mixture F-12 } \\
\quad(\mathrm{DMEM} / \mathrm{F} 12)\end{array}$ & $\begin{array}{l}\text { Lonza } \\
\text { Gibco (Carlsbad, CA, USA) } \\
\text { Gibco }\end{array}$ \\
\hline HUVEC medium & EGM-2 Endothelial Cell Growth Medium-2 & Lonza \\
\hline Serum free medium (SFM) & $\begin{array}{l}\text { ITS }(1.15 \mu \mathrm{M} \text { insulin, } 6.65 \mu \mathrm{g} / \mathrm{ml} \text { Transferrin, } 6.65 \mathrm{ng} / \mathrm{ml} \text { seleniuous } \\
\text { acid) } \\
2.56 \mathrm{mM} \text { L-glutamine } \\
1 \% \text { Bovine serum albumin } \\
2.8 \mathrm{mM} \text { Sodium Pyruvate } \\
50 \mathrm{U} / \mathrm{ml} \text { Penicillin } / 50 \mu \mathrm{g} / \mathrm{ml} \text { Streptomycin } \\
0.1 \mathrm{nM} \mathrm{3,3',5-Triiodo-L-thyronine} \mathrm{sodium} \mathrm{salt} \\
10 \mathrm{ng} / \mathrm{ml} \text { Vascular endothelial growth factor A } \\
1 \mathrm{ng} / \mathrm{ml} \text { fibroblast growth factor } 2 \\
100 \mu \mathrm{g} / \mathrm{ml} \text { Ascorbic acid } \\
50 \mathrm{ng} / \mathrm{ml} \text { heparin } \\
0.2 \mu \mathrm{g} / \mathrm{ml} \text { hydrocortisone } \\
\text { in DMEM/F12 }\end{array}$ & $\begin{array}{l}\text { BD Biosciences (NJ, USA) } \\
\text { Gibco } \\
\text { Biosera (Boussens, France) } \\
\text { Gibco } \\
\text { Gibco } \\
\text { Sigma Aldrich (MO, USA) } \\
\text { R\&D Systems (Abingdon, } \\
\text { UK) } \\
\text { R\&D Systems } \\
\text { Sigma-Aldrich } \\
\text { Sigma Aldrich } \\
\text { Sigma Aldrich } \\
\text { Gibco }\end{array}$ \\
\hline Monocyte medium & $\begin{array}{l}50 \mathrm{U} / \mathrm{ml} \text { Penicillin/Streptomycin } \\
\text { in RPMI-1640 }\end{array}$ & $\begin{array}{l}\text { Gibco } \\
\text { ATCC }\end{array}$ \\
\hline ATE medium & $\begin{array}{l}1700 \mu \mathrm{g} / \mathrm{ml} \text { of ATE } \\
10 \% \mathrm{HS} \\
2 \mathrm{mM} \mathrm{L} \text {-Glutamine } \\
50 \mathrm{U} / \mathrm{ml} \text { Penicillin/Streptomycin } \\
\text { in DMEM/F12 }\end{array}$ & $\begin{array}{l}\text { Own production, see } \\
\text { Chapter } 4.4 \\
\text { Lonza } \\
\text { Gibco } \\
\text { Gibco } \\
\text { Gibco }\end{array}$ \\
\hline $\begin{array}{l}\text { Monocyte-to-macrophage } \\
\text { medium }\end{array}$ & $\begin{array}{l}10 \% \text { inactivated Human serum } \\
\text { in RPMI- } 1640\end{array}$ & $\begin{array}{l}\text { Lonza } \\
\text { ATCC }\end{array}$ \\
\hline
\end{tabular}


Bergisch Gladbach, Germany) and MACS magnetic separator midiMACS (Miltenyi Biotec) were utilized according to the manufacturer instructions. Cells were suspended to buffer and Pan $\mathrm{T}$ cell biotin-antibody cocktail was added and incubated at $4{ }^{\circ} \mathrm{C}$ for $10 \mathrm{~min}$. Pan $\mathrm{T}$ cell Microbead cocktail was then added and incubated at $4{ }^{\circ} \mathrm{C}$ for $15 \mathrm{~min}$. After wash and centrifugation at $300 \mathrm{~g}$ for $10 \mathrm{~min}$, the supernatant was removed, and cells were suspended to the buffer and added into the MACS LS column (Miltenyi Biotec). The unlabeled flow-through is the $T$ cell population, which was not utilized in the study, and cells attached to the column include monocytes. Monocytes were cultured in monocyte medium (Table 1). Cells were cryopreserved in RPMI-1640 (ATCC) supplemented with 10\% DMSO (Sigma), 10\% human serum (Lonza type $\mathrm{AB}$ filtered) and 50 $\mathrm{U} / \mathrm{ml}$ Penicillin and streptomycin (Gibco).

\section{Differentiation of monocytes to macrophages}

Monocytes, isolated from blood as well as commercial monocytes i.e. CD14 + Monocytes from Peripheral blood, single donor (PromoCell, C-12909), were utilized. After thawing, the cells were cultured in a $25 \mathrm{~cm}^{2}$ culture bottle in monocyte-to-macrophage medium (Table 1) to differentiate the monocytes towards macrophages. Human serum in the medium differentiates monocytes into macrophages (Andreesen et al. 1983; Musson 1983). For the first $24 \mathrm{~h}$ after thawing, the cells were allowed to recover. Then fresh medium was changed. After 3 days, some of monocytes had attached to the bottom and differentiated to macrophages, whereas some of monocytes were growing in suspension. Every 4-5 days, half of the medium was changed, and the morphology of the cells was monitored by microscope. After 10 days, cells growing were subcultured with ratio of 1:2 into $25 \mathrm{~cm}^{2}$ culture bottles. After culturing the cells for 24 days, the macrophages were differentiated and ready to be used in the construction of the in vitro models. Maturity was tested with methods presented in paragraph "Analysis of isolated and differentiated macrophages". Detachment of macrophages was done by Macrophage detachment solution DXF (PromoCell, C-41330) and scraping with a cell scraper.
Isolation of cells from adipose tissue for the personalized model

CD11b positive cells and endothelial cells (CD31 positive) were isolated from the same adipose tissue sample as hASC.

\section{Isolation of CDI1b positive cells from adipose tissue}

CD11b selection was used to obtain immune cells (mainly monocytes/macrophages) from adipose tissue. The adipose tissue was cut into small pieces and incubated in $0.15 \%$ collagenase I (Gibco) for $12 \mathrm{~h}$. This was then centrifuged at $600 \mathrm{~g}$ for $10 \mathrm{~min}$ followed by the removal of the supernatant. To remove red blood cells by bursting them, the pellet was incubated in sterile water for $2 \mathrm{~min}$. DMEM/F12 (Gibco) supplemented with 1\% L-glutamine (Gibco), 10\% Human serum (Lonza) and $50 \mathrm{U} / \mathrm{ml}$ Penicillin and streptomycin (Gibco) was added to dilute the water and this was centrifuged at $600 \mathrm{~g}$ for $10 \mathrm{~min}$ which resulted in cell pellet (the tissue was processed similarly up to this step also for endothelial cell isolation). The cell pellet was resuspended and filtered through $100 \mu \mathrm{m}$ mesh. The $\mathrm{CD} 11 \mathrm{~b}$ positive cells were isolated utilizing mouse/human CD11b Microbeads kit (Miltenyi Biotec) and MACS magnetic separator miniMACS (Miltenyi Biotec) according to manufacturer's instructions. Cells in the adipose tissue derived cell suspension were counted and divided $1 \times 10^{7}$ cells per tube followed by incubation with CD11b antibody for 10 min at $+4{ }^{\circ} \mathrm{C}$ and wash with MACS running buffer. Cell suspension was then centrifuged at $300 \mathrm{~g}$ for $5 \mathrm{~min}$, supernatant was removed, and fresh running buffer added. This suspension was then run through a MACS column with pre separation filter (Miltenyi Biotec). Column was washed three times before collecting the cells captured into the column. Cells were cultured in Monocyte medium (Table 1) prior to analysis of their functionality.

\section{Isolation of endothelial cells from adipose tissue}

Pluribead anti-human CD31 S-bead kit (PluriSelect, Leipzig, Germany) was utilized for positive selection of endothelial cells from adipose tissue. The adipose tissue was treated as described in paragraph "Isolation of CD11b positive cells from adipose tissue" until cell pellet was reached. The pellet was resuspended in the 
buffer of the Pluribead kit and the cell number was adjusted to be max $5 \times 10^{6}$ target cells $/ \mathrm{ml}$ and this suspension was filtered through provided filter. CD31 S-Pluribeads were then mixed with the cell suspension and incubated at room temperature (RT) for $30 \mathrm{~min}$ on rotation on MACSmix ${ }^{\mathrm{TM}}$ Tube Rotator (Miltenyi Biotec). This suspension was then filtered through equilibrated strainers. The strainer was then transferred on top of sterile $50 \mathrm{ml}$ tube, washed and detachment buffer was added and incubated for $10 \mathrm{~min}$ at RT. Cells were released from the strainer and strainer was washed with HUVEC medium. This suspension was then centrifuged $10 \mathrm{~min}$ at $300 \mathrm{x} \mathrm{g}$ without brake. The pellet was suspended into EGM-2 Endothelial Cell Growth Medium-2 medium (Lonza) and transferred into $25 \mathrm{~cm}^{2}$ culture bottle.

Preparation of adipose tissue extract

In order to obtain adipose tissue extract (ATE) (Lopez et al. 2016, 2018; Sarkanen et al. 2012a, b), human adipose tissue specimens were mechanically cut into small pieces and incubated in DMEM/F12 (Gibco) in $+37{ }^{\circ} \mathrm{C}$ for $1-24 \mathrm{~h}$. After the incubation, the liquid was collected, centrifuged and sterile filtered and stored in $-70{ }^{\circ} \mathrm{C}$ until use. Protein concentrations of ATE was determined utilizing Pierce BCA Protein Assay Kit (Thermo Scientific, Waltham, MA) according to manufacturer's instructions using bovine serum albumin as a standard. Results were measured after 30 min incubation at $37{ }^{\circ} \mathrm{C}$ at $562 \mathrm{~nm}$ with Varioskan Flash Multimode Reader (Thermo Scientific).

Analysis of isolated and differentiated macrophages and endothelial cells

\section{LDL uptake by CDI1b positive cells and endothelial cells}

Low density lipoprotein 488 (LDL-488, Molecular probes, Eugene, Oregon, USA) at $10 \mu \mathrm{g} / \mathrm{ml}$ concentration was added on cells and incubated for $4 \mathrm{~h}$ at $37^{\circ} \mathrm{C}$. After incubation, cells were washed and analyzed by microscope and imaged with automated imaging system Cell-IQ (Chipman Technologies, Tampere, Finland).
Test of engulfment function of macrophages

To ensure the successful differentiation of macrophages, fluorescein stained cell debris was fed to the macrophages. This debris was produced by staining hASC with cell membrane label mini-67 PKH67 Green fluorescent cell linker kit (Sigma) according to manufacturer's instructions. Cells were washed with PBS (Gibco), detached from the culture bottle, centrifuged $400 \mathrm{x} \mathrm{g}$ for $5 \mathrm{~min}$ followed by removal of supernatant. The pellet was suspended into residual supernatant. Diluent was added on cells followed by addition of PKH67 at concentration of $4 \mu \mathrm{M}$. This was incubated for $5 \mathrm{~min}$ in RT and mixed once during this time. Equal amount of hASC medium was added to the tube and centrifuged $400 \mathrm{~g}$ for $10 \mathrm{~min}$. Washing was performed two times in a fresh tube using hASC medium. This stained cell suspension was then frozen and thawed for four times. The breakdown of cells was confirmed by microscopy. Cell debris was stored at $-20{ }^{\circ} \mathrm{C}$ until used. Stained cell debris was added on macrophages and the engulfment of these particles was visualized and recorded for $5 \mathrm{~h}$ using automated imaging system, Cell-IQ (Chipman technologies).

\section{Hematoxylin-eosin staining of macrophages}

Hematoxylin-eosin staining was performed by pipetting cell suspension containing macrophages on a microscopy glass and embedding them with TissueTek $^{\circledR}$ O.C.T. Compound (Miles inc. Elkhart, IN, USA). Absolut alcohol, 94\% ethanol, 70\% ethanol and distilled water were added on the glass in sequence each for $1 \mathrm{~min}$. Mayer hematoxylin was added for $10 \mathrm{~min}$ and this was rinsed with water and then with distilled water. $1 \%$ Eosin was added for $2 \mathrm{~min}$ followed by $96 \%$ ethanol, absolute ethanol and xylene. Cells were imaged with Nikon Eclipse TS100 inverted fluorescence microscope (Nikon, Tokyo, Japan) and Nikon digital sight DS-U2 -camera (Nikon).

In vitro cell models developed in the study

\section{Adipocyte-macrophage Model}

The development of adipose tissue depicting cell models was started by combining the macrophages and hASC i.e. creating Adipocyte-Macrophage model (AMM). In this model adipogenesis was induced with 
ATE and the angiogenesis induction medium (serum free medium, SFM, Table 1) was utilized to obtain more mature adipocytes as published earlier (Huttala et al. 2018). SFM was also used to confirm that it is suitable medium for sustaining macrophages. No cytokines were added except those found in ATE.

hASC were plated on 48 well plate at density of 20,000 cells $/ \mathrm{cm}^{2}$ in hASC medium (Table 1 ). Detachment of hASC was done by Tryple Express (Gibco). Monocytes isolated from blood were seeded on top of hASC at density of 7500 cells $/ \mathrm{cm}^{2}$ in the Monocyte medium (Table 1). One day after the plating, the medium was changed to ATE medium (Table 1). On day 4 , medium was changed to SFM (Table 1) which was replenished every third day. Analysis were performed on day 13. To analyze the triglyceride accumulation Adipored (Lonza) reagent was utilized and for viability measurements, WST-1 (Roche, Basel, Switzerland) reagent was utilized.

Control (AMM without macrophages) was cultured in exactly same manner as AMM but lacked the macrophages. The medium compositions and protocol summary can be seen in Table 1 and 2, respectively.

\section{Adipocyte-macrophage model with IFN $\gamma$ \\ and vascularized adipose tissue model \\ with macrophages with IFN $\gamma$}

We further optimized the AMM to allow studies of effects of cytokines. The optimization was done keeping in mind the addition of endothelial cells in the later stage. Hence the protocol was developed so that this protocol would also allow the addition of endothelial cells without changes to the protocol. IFN $\gamma$ was utilized as example cytokine.

The following protocol was developed to construct Adipocyte-Macrophage model with IFN $\gamma$ (AMMI). On day 0 , hASC plated on 48 well plate at density of 20,000 cells $/ \mathrm{cm}^{2}$ in hASC medium (Table 1). On day 1 , the medium was changed to ATE medium. ATE has been previously shown to induce natural adipogenesis
(Sarkanen et al. 2012a). On day 8, the medium was changed to serum free medium (Table 1). On day 11, the medium was replenished, and macrophages were added at a density of 34,000 cells $/ \mathrm{cm}^{2}$ in serum free medium. ATE was added in the wells in final protein concentration of $387.1 \mu \mathrm{g} / \mathrm{ml}$.

On day 12, $20 \mathrm{ng} / \mathrm{ml}$ of IFN $\gamma$ (R\&D Systems) was added in wells and on day $13, \operatorname{IFN} \gamma$ was added to concentration of $60 \mathrm{ng} / \mathrm{ml}$. On day 21, the whole medium from the wells was collected, frozen and stored in $-80{ }^{\circ} \mathrm{C}$ until analysis by ELISA. To analyze the triglyceride accumulation Adipored (Lonza) reagent was utilized. Control was cultured in exactly same manner as the AMMI except lacked macrophages. The media used and protocol outlines can be seen in Tables 1 and 3, respectively.

To analyze the cytokine content of the medium samples collected from AMMI, Human obesity ELISA Strips (Signosis, Silicon valley, CA, USA) containing TNF $\alpha$, insulin-like growth factor 1 (IGF), resistin, interleukin 6 (IL-6), plasminogen activator inhibitor 1 (PAI), transforming growth factor $\beta$ (TGF $\beta$ ), adiponectin and leptin were used according to manufacturer's instructions. Standards, controls and samples were incubated on the plate for $1 \mathrm{~h}$ at RT with shaking. After washes, the biotin-labelled antibody mixture was incubated for $1 \mathrm{~h}$ at RT with shaking followed by washing steps. Streptavidin-HRP conjugate was added and incubated for $45 \mathrm{~min}$ at RT with shaking. After washes, substrate was added and incubated for $20 \mathrm{~min}$ at which point the stop solution was added. The optical density was measured at $450 \mathrm{~nm}$ with plate reader Varioskan Flash (Thermo Scientific).

To construct the Vascularized Adipose Tissue model with Macrophages with IFN $\gamma$ (VATMI) similar protocol to AMMI was developed, except for the additions. On day 7, HUVEC were plated in EGM-2 medium (Lonza) at density of 4000 cells $/ \mathrm{cm}^{2}$. The cells were added into the medium in which hASC had grown for the week. Control samples were cultured in

Table 2 Construction of the Adipocyte-Macrophage model (AMM) and its control

\begin{tabular}{|c|c|c|c|c|c|c|}
\hline Model/control & Day 0 & Days 1 & Day4 & Day 7 & Day 9 & Day 13 \\
\hline AMM without macrophages & Plating of hASC & ATE medium & SFM & SFM & SFM & Analysis \\
\hline AMM & Plating of hASC and monocytes & ATE medium & SFM & SFM & SFM & \\
\hline
\end{tabular}


Table 3 Construction of the Adipocyte-Macrophage model with IFN $\gamma$ (AMMI) and vascularized adipose tissue model with IFN $\gamma$ (VATMI). SFM = serum free medium

\begin{tabular}{|c|c|c|c|c|c|c|c|c|}
\hline Model & Day 0 & Days 1-7 & Day 7 & $\begin{array}{l}\text { Days } \\
8-10\end{array}$ & Day 11 & Day 12 & Day 13 & Day 21 \\
\hline AMMI & $\begin{array}{l}\text { Plating } \\
\text { of } \\
\text { hASC }\end{array}$ & $\begin{array}{l}\text { ATE } \\
\text { medium }\end{array}$ & & SFM & $\begin{array}{l}\text { Plating of macrophages, } \\
\text { SFM supplemented with } \\
\text { ATE }\end{array}$ & $\begin{array}{l}20 \mathrm{ng} / \mathrm{ml} \\
\text { of } \\
\text { IFN } \gamma\end{array}$ & $\begin{array}{l}\text { Addition of } \\
60 \mathrm{ng} / \mathrm{ml} \\
\text { IFN } \gamma\end{array}$ & Analysis \\
\hline $\begin{array}{l}\text { AMMI without } \\
\text { macrophages }\end{array}$ & $\begin{array}{l}\text { Plating } \\
\text { of } \\
\text { hASC }\end{array}$ & $\begin{array}{l}\text { ATE } \\
\text { medium }\end{array}$ & & SFM & SFM with ATE & $\begin{array}{l}20 \mathrm{ng} / \mathrm{ml} \\
\text { of } \\
\text { IFN } \gamma\end{array}$ & $\begin{array}{l}\text { Addition of } \\
60 \mathrm{ng} / \mathrm{ml} \\
\text { IFN } \gamma\end{array}$ & \\
\hline VATMI & $\begin{array}{l}\text { Plating } \\
\text { of } \\
\text { hASC }\end{array}$ & $\begin{array}{l}\text { ATE } \\
\text { medium }\end{array}$ & $\begin{array}{r}\text { Plating of } \\
\text { HUVEC }\end{array}$ & SFM & $\begin{array}{l}\text { Plating of macrophages, } \\
\text { SFM supplemented with } \\
\text { ATE }\end{array}$ & $\begin{array}{l}20 \mathrm{ng} / \mathrm{ml} \\
\text { of } \\
\text { IFN } \gamma\end{array}$ & $\begin{array}{l}\text { Addition of } \\
60 \mathrm{ng} / \mathrm{ml} \\
\text { IFN } \gamma\end{array}$ & \\
\hline $\begin{array}{l}\text { VATMI } \\
\text { without } \\
\text { macrophages }\end{array}$ & $\begin{array}{l}\text { Plating } \\
\text { of } \\
\text { hASC }\end{array}$ & & $\begin{array}{l}\text { Plating of } \\
\text { HUVEC }\end{array}$ & SFM & $\begin{array}{l}\text { SFM supplemented with } \\
\text { ATE }\end{array}$ & $\begin{array}{l}20 \mathrm{ng} / \mathrm{ml} \\
\text { of } \\
\text { IFN } \gamma\end{array}$ & $\begin{array}{l}\text { Addition of } \\
60 \mathrm{ng} / \mathrm{ml} \\
\text { IFN } \gamma\end{array}$ & \\
\hline
\end{tabular}

the same manner as VATMI, except the macrophages were not added into the control wells. The media used and protocol outlines can be seen in Tables 1 and 3 , respectively. To analyze the cytokine content of the medium samples collected from VATMI, Human inflammation ELISA strips (Signosis) containing $\mathrm{TNF} \alpha$, granulocyte-colony stimulating factor (GCSF), granulocyte-macrophage colony-stimulating factor (GM-CSF), interleukin 1a (IL-1a) and 8 (IL8), interferon gamma-induced protein 10 (IP-10 also known as CXCL10) and rantes were used according to manufacturer's instructions and as described above.

Analysis of models

\section{Viability and triglyceride accumulation}

The relative number of living cells was analyzed by WST-1 (Roche) with 1-h incubation. Absorbance was measured at $450 \mathrm{~nm}$ with Varioskan flash multimode reader (Thermo Fischer Scientific).

Triglyceride accumulation to the cell cultures was measured with Adipored assay reagent (Lonza) with 10 min incubation at RT after the WST-1 analysis. Fluorescence was measured with Varioskan flash multimode reader (Thermo Fischer Scientific), with excitation at $485 \mathrm{~nm}$ and emission at $572 \mathrm{~nm}$. The Adipored values were normalized with WST-1 values to obtain relative amount of triglycerides per cell.

\section{Immunocytochemical staining}

To visualize the vascular-like network formation and macrophages in the co-culture immunocytochemical stainings were performed. The immunocytochemical staining was performed as described earlier (Huttala et al. 2015) except for the fixative used here was $4 \%$ paraformalaldehyde at RT for $20 \mathrm{~min}$. After fixation, the cells were permeabilized with $0.5 \%$ Triton-X100 (MP Biochemicals, Ohio, USA) and non-specific binding sites were blocked with $10 \%$ BSA (Roche). Primary antibody dilution in $1 \%$ BSA in PBS was applied on the cells. Primary antibodies were $\alpha$ Antivon Willebrant factor IgG (produced in rabbit, Sigma), CD11b and CD68 (both from BD). Secondary antibodies were also applied in 1\% BSA in PBS solution. Secondary antibodies used were TRITC-labeled goat polyclonal antibody anti-rabbit IgG (Sigma), FITClabeled goat polyclonal antibody anti-mouse $\mathrm{IgG}$ (Sigma), DAB Peroxidase (HRP) Substrate Kit, (Vector labs) and V450 (BD). After immunocytochemical staining the vascular-like network was photographed with Nikon Eclipse TS100 inverted fluorescence microscope (Nikon) and Nikon digital sight DS-U2 -camera (Nikon). Images were further processed with NIS Elements (Nikon) and Adobe Photoshop CS3-software (Adobe Systems Incorporated, San Jose, CA, United States). 
Statistical analysis

All results were plotted and statistical analyzes were performed with GraphPadPrism (GraphPad Software Inc., California, USA). Results are depicted as mean \pm standard deviation. Triglyceride accumulation comparisons ( $\mathrm{n}=6$ in all) analyzed with MannWhitney test. For ELISA $(\mathrm{n}=2)$ comparisons were performed with Two-way ANOVA with Sidak's multiple comparisons test. Differences were considered significant when $* \mathrm{p}<0.05, * * \mathrm{p}<0.01$ and $* * * \mathrm{p}<0.001$.

\section{Results}

Isolated cells are functional

As one of the goals was to be able to construct the model from one lipid sample, we tested the isolation methods for isolation of macrophages and endothelial from adipose tissue. When one patient model is not needed, the monocytes are isolated from blood and differentiated to macrophages. Also, endothelial cells are routinely obtained from umbilical cord (HUVEC). Macrophages and endothelial cells from all sources were tested for their correct phenotype and functional features. The isolated monocytes, which were differentiated towards macrophages, engulfed the cell debris they were given (Fig. 1). The uptake of LDL was also seen in both macrophages and endothelial cells which shows they are functioning normally. In addition, the staining of the macrophages proved them positive for CD11b and CD68 (Fig. 1).

Presence of macrophages affects the lipid accumulation in adipocytes

The development of adipose tissue depicting cell models was started by combining the macrophages and hASC i.e. creating Adipocyte-Macrophage model (AMM). In this model adipogenesis was induced with ATE, a natural adipogenesis inducer. The impact of macrophages on lipid accumulation was studied in AMM by comparing it with AMM without macrophages. Figure 2a shows the morphology of the cell models. The interaction of adipocytes and macrophages leads to larger lipid vesicles in adipocytes (Fig. 2a). This difference was also seen in the analysis of amount of triglycerides per cell (cell number was relative total cell number of the model determined by WST-1) however, the difference was not significant (Fig. 2b). The larger lipid vesicles in adipocytes could indicate more mature state i.e. further and better differentiation, of the adipocytes in presence of macrophages.

Adipocyte-Macrophage model with IFN $\gamma$

The Adipocyte-Macrophage model was further optimized to allow studies of cell-cell interactions together with studies of the effect of IFN $\gamma$ (now called AMMI). This modification also allows other cytokines to be studied in the future. In this co-culture setting, the differentiation of hASC to adipocytes was studied by analyzing the lipid accumulation with or without the presence of macrophages. Macrophages attached on top of the hASC, which were differentiated into adipocytes (Fig. 3a). The immunostaining image (Fig. 3b) shows macrophage stained with CD11b in red and triglycerides inside the adipocytes in green (stained with AdipoRed). The triglyceride accumulation in adipocytes was significantly increased in the presence of macrophages and IFN $\gamma$ (Fig. 3b). IFN $\gamma$ has not changed the total body weight in animal studies to (Rocha et al. 2008) which could indicate the role of macrophages in increasing the lipid accumulation in presence of IFN $\gamma$.

Secretion of proteins in AMMI was analyzed from the medium samples collected on day 21 of the culture (Fig. 4). Studied proteins were TNF $\alpha$, IGF, resistin, IL-6, PAI, TGF $\beta$, adiponectin and leptin as these are proteins found in adipose tissue and they are secreted mainly from adipocytes and immune cells (Makki et al. 2013). Addition of macrophages increased the secretion of adiponectin significantly. This was surprising as adiponectin favors insulin-sensitivity and IFN $\gamma$ knockout rather than presence of IFN $\gamma$ has been linked to modest improvements in insulin sensitivity and decreased adipocyte size (O'Rourke et al. 2012). Secretion of adipocyte and obesity related proteins IGF, PAI, and Leptin were increased in AMMI compared to AMMI without macrophages. Resistin secretion seemed to increase but due to the high variation of control treatment, this cannot be confirmed. Production of pro-inflammatory cytokines TNF $\alpha$ and IL- 6 was also increased in AMMI. TGF $\beta$ 

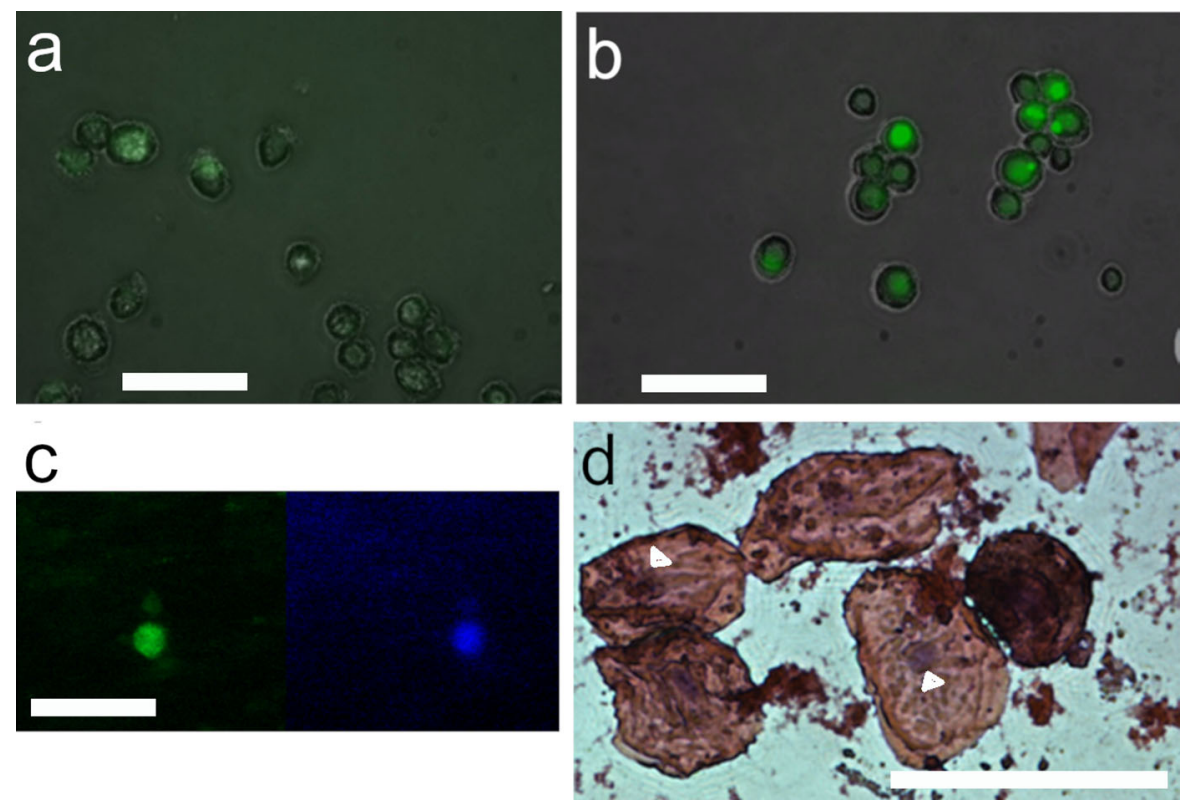

Fig. 1 Identity and functionality of macrophages. Macrophages engulfed dead cell parts (shown in green), imaged with Cell-IQ (Chipman technologies). In image a in the first time point, the well of cell culture plate is still full of small particles seen as fuzzy green background. b At $5 \mathrm{~h}$ time point, the background is clean, because macrophages have engulfed the

dead cell debris. c Double positive macrophage (CD68-FITC (green) and CD11b-V450 (blue)). d Hematoxylin-eosin stained macrophages isolated from adipose tissue. Nuclei of the macrophages marked with arrowhead. $\mathbf{c}$ and $\mathbf{d}$ obtained with Nikon Eclipse TS100 inverted fluorescence microscope and digital sight DS-U2 -camera. Scale bar $50 \mu \mathrm{m}$

a

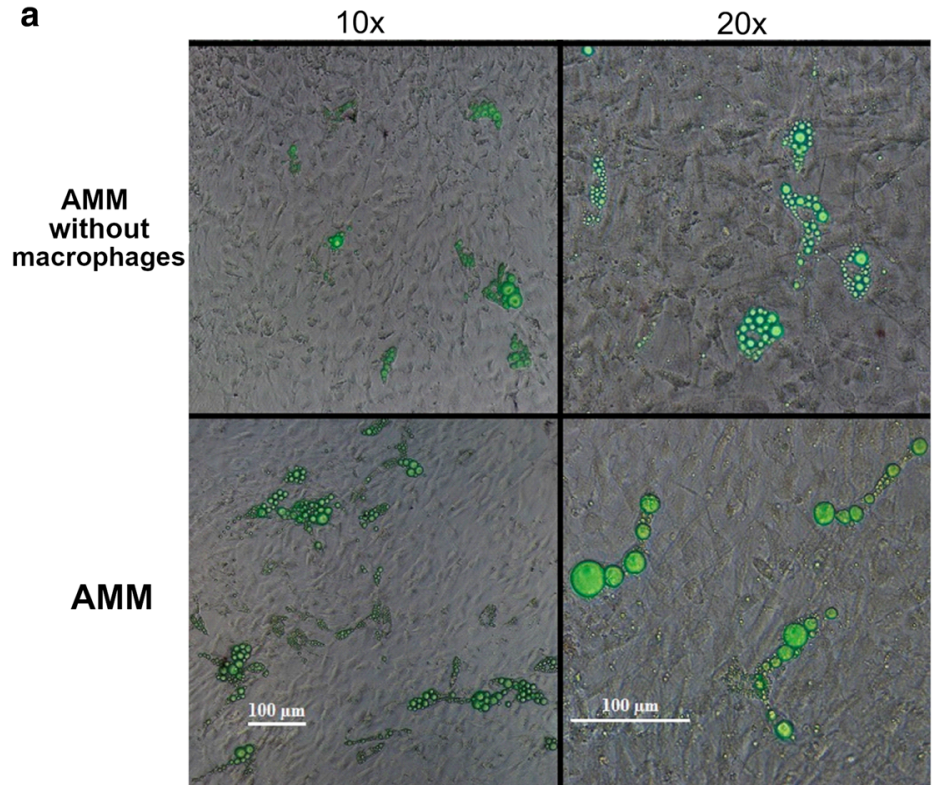

b

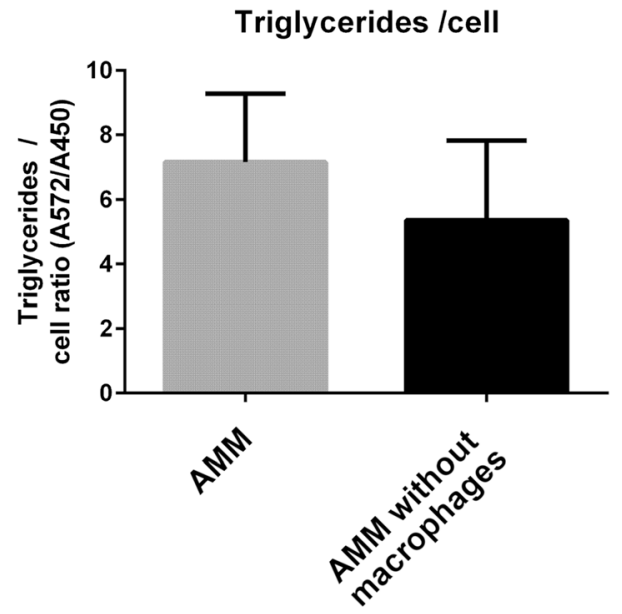

columns $100 \mu \mathrm{m}$. b Triglyceride accumulation per cell calculated from AdipoRed (total amount of triglycerides) and WST-1 (relative cell number) results. Images obtained with Nikon Eclipse TS100 inverted fluorescence microscope and digital sight DS-U2 -camera 


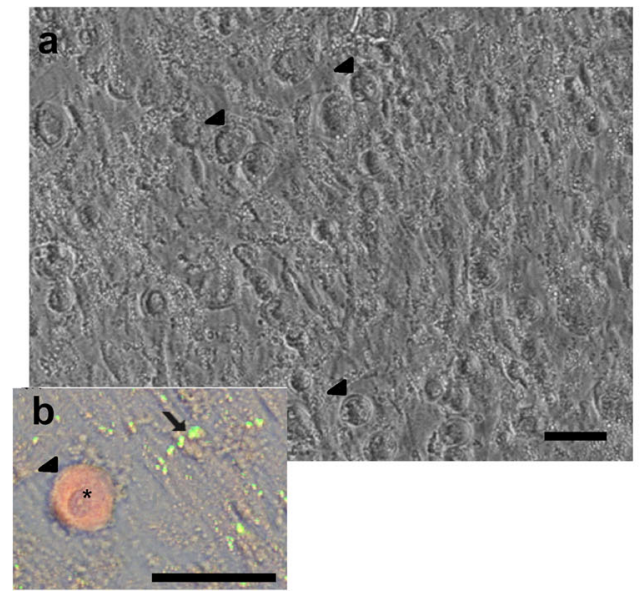

Fig. 3 Adipocyte-Macrophage model with IFN $\gamma$ (AMMI). Image a Phase contrast image of adipocytes and macrophages. Image b Close-up of macrophage in the culture: phase contrast image combined with AdipoRed (green) stained adipocytes and macrophage stained with CD11b (red). Macrophages marked with arrow heads and lipids stained with adipored marked with

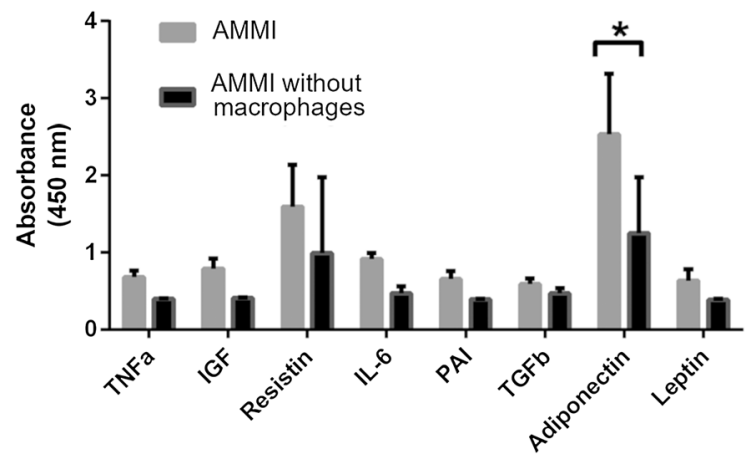

Fig. 4 Cytokine expression in Adipocyte-Macrophage model with IFN $\gamma$ (AMMI). Amounts of TNF $\alpha$, IGF, Resistin, IL-6, PAI, TGF $\beta$, Adiponectin and leptin were determined. Adiponectin shows significant increase in the presence of macrophages. Results depicted as mean $\pm \mathrm{SD}, * \mathrm{p}<0.05$

secretion was not changed whether macrophages were present in the culture or not.

Vascularized adipose tissue model with macrophages

To study the effect of vascularization on lipid accumulation and protein secretion, the AMMI was further developed to form Vascularized adipose tissue model with macrophages and the same IFN $\gamma$ additions as AMMI (VATMI). Vasculature is important part of adipose tissue and the diseases related to adipose
C

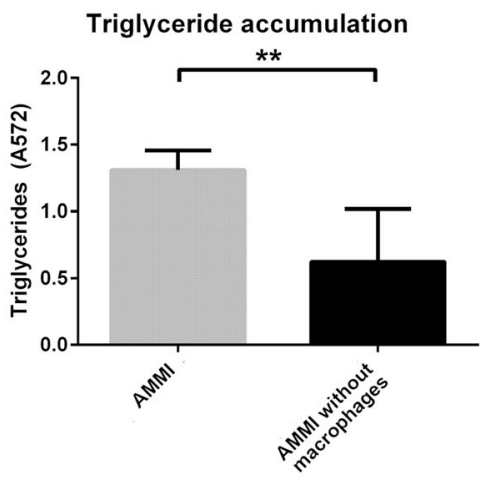

arrow. Macrophage nucleus can be seen in the close-up (asterisk). Obtained with Nikon Eclipse TS100 inverted fluorescence microscope and digital sight DS-U2 -camera. Scale bar $50 \mu \mathrm{m}$. c Triglyceride accumulation significantly differs between cultures with and without macrophages. Results depicted as mean $\pm \mathrm{SD}, * * \mathrm{p}<0.01$

tissue. Hence to properly depict the biology of adipose tissue all three systems need to be present; vasculature, adipocytes and immune cells. By combining the hASC, HUVEC and macrophages, we were able to achieve formation of vascular structures (Fig. 5a), differentiation of adipocytes, which collect triglycerides (Fig. 5b and c), and the activation of macrophages in the same culture. The addition of macrophages increased triglyceride accumulation in adipocytes also in the presence of vasculature. However, due to the high variation in the control this was not found significant.

Secretion of TNF $\alpha$, G-CSF, GM-CSF, IL-1a, IL-8, IP-10 and rantes was studied from medium samples collected from VATMI on day 21. These selected proteins are found in adipose tissue and are produced by adipocytes, endothelial cells or immune cells (Makki et al. 2013; Nosalski and Guzik 2017). The focus was in studying the effect of macrophages/their absence in this model system and not in comparing AMMI and VATMI to each other. In addition to proteins secreted by adipocytes and immune cells, we looked at proteins produced by endothelial cells or production is affected by endothelia cells (Kawai et al. 1999; Mariotti et al. 2006) and which can influence the formation of vasculature (Bodnar et al. 2006; Li et al. 2003). Expressions of IL-8 and IP-10 (CXCL10), both inflammation related cytokines, increased in the 

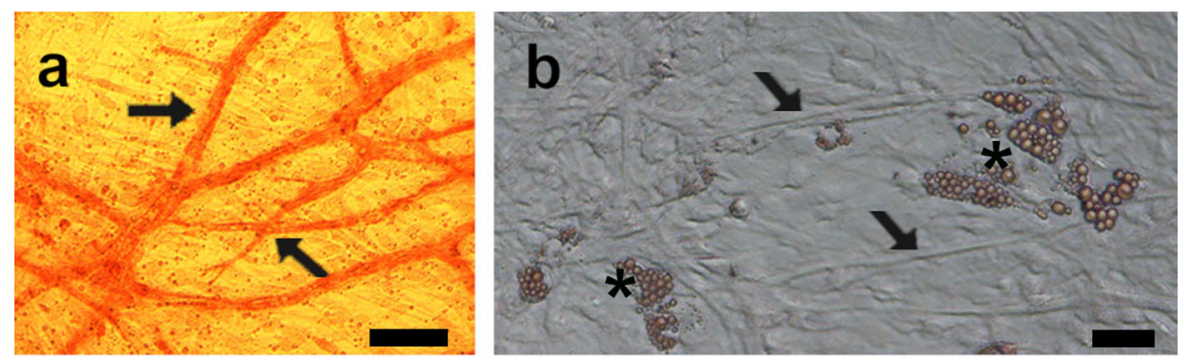

\section{Triglyceride accumulation}

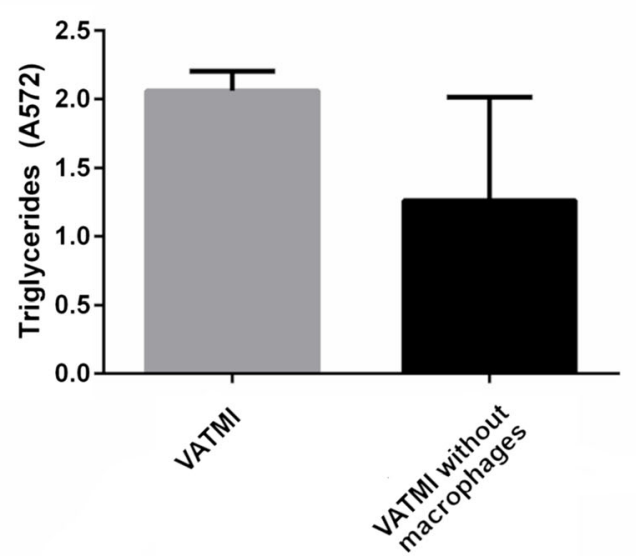

Fig. 5 Characteristics of Vascularized Adipose Tissue model with Macrophages with IFN $\gamma$ (VATMI). a Vasculature in VATMI stained with DAB. b Adipocytes and vessel structures in the phase contrast image of VATMI. Both obtained with Nikon Eclipse TS100 inverted fluorescence microscope and

presence of macrophages (Fig. 6), although the change was not significant. Overall, the presence of macrophages did not lead to change in expression or decreased the expression of proteins in VATMI

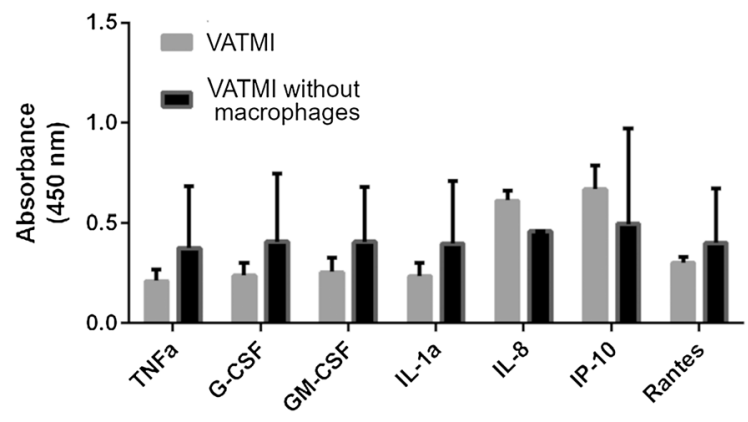

Fig. 6 Cytokine expression in Vascularized Adipose Tissue model with Macrophages with IFN $\gamma$ (VATMI). Increase is seen in IL-8 and IP-10 although none of the differences were significant. Results depicted as mean $\pm \mathrm{SD}$ digital sight DS-U2 -camera. Vasculature marked with arrows and adipocytes with asterisks. Scale bar in both $100 \mu \mathrm{m}$. c Triglyceride accumulation differs between cultures with and without macrophages. Results depicted as mean \pm SD

however the large variations in results do not allow reliable interpretation.

\section{Discussion}

We have previously developed in vitro vascular structures (Huttala et al. 2015) and vascularized adipose tissue model (Huttala et al. 2018), which were modified in the present study to construct vascularized adipose tissue models with macrophages. We were able to produce extensive vascular network, adipocyte differentiation and allow functionality of the macrophages in single co-culture set-up. Both Adipocyte-Macrophage model (consisting of hASC differentiated to adipocytes and macrophages) and Vascularized adipose tissue model with macrophages (consisting of hASC differentiated to adipocytes, 
macrophages and endothelial cells forming vasculature) are relevant tools for adipose tissue research.

In these in vitro models, the effect of macrophages on lipid accumulation as well as on inflammation marker expression was studied. In addition, to enable the use of this model in the context of personalized medicine, the proof-of-concept method of isolation of hASC, monocytes and microvascular endothelial cells from single patient was created. The results show that the model could be set-up by using cells from one patient as long as the adipose tissue sample is large enough. In addition, the presence of macrophages seemed to lead to larger lipid storages per adipocyte. However, the presence of vasculature seemed to attenuate the changes in protein secretion caused by the macrophages.

Due to the growing incidence of obesity, the adipose tissue research is more and more important in determining the mechanisms and finding novel treatment options for obesity and the related complications. In vitro models are known to be more relevant than animal models and therefore, the developed in vitro models should contain human cells. ASC are excellent cell type for relevant in vitro models. The definition of mesenchymal stem cells, including ASC, is that they must express CD105, CD73 and CD90 (Dominici et al. 2006). The characterization of the cells used in in vitro models is as important as the characterization of the model. We have previously characterized the hASC and HUVEC obtained with our optimized isolation protocol (Huttala et al. 2015). Hence, these cells have routine batch quality control and are not discussed further here. However, the isolated monocytes, the activated macrophages, adipose tissue derived macrophages and adipose tissue derived endothelial cells are characterized in this study. The monocytes, which were differentiated to macrophages, and the adipose tissue derived macrophages were all confirmed to be active and functional determined by their ability to clear out dead cell debris and uptake LDL. Due to the heterogeneity of macrophages (Gordon and Taylor 2005), the use of adipose tissue derived macrophages can be justified in in vitro models aiming to depict the inflammation in adipose tissue.

Although HUVEC are well studied and commonly used endothelial type in tissue engineering, the use of HUVEC has been criticized as they are derived from macro vessels. Hence, more relevant cell sources are needed, especially now that studies are showing more and more differences in characteristics between the endothelial cells isolated from different sources (Marcu et al. 2018). Here we isolated the endothelial cells from adipose tissue and confirmed the functionality with the uptake of LDL. These tissue specific human endothelial cells are highly relevant cell source for in vitro model development.

For needs of personalized medicine, the cells used in the in vitro models need to be obtained from single donor with as little additional disturbance to the patient as possible. Here we tested the methods and characterized the isolated cells and were able to isolate all the necessary cell types, macrophages, endothelial cells and hASC, from one patient adipose tissue sample. Hence, after further testing this in vitro model system of Vascularized adipose tissue model with macrophages could be utilized in the research of adipose tissue related diseases and in the screening of suitable treatment options for specific patients and patient groups.

The insulin metabolism contains many players, which also impact the formation of insulin resistance. The cell intrinsic mechanisms include mitochondrial dysfunction, oxidative and endoplasmic reticulum (ER) stress, and ectopic lipid deposition (Chawla et al. 2011). Alterations in circulating adipokines and fatty acids, and metabolic tissue inflammation are the dominant cell extrinsic pathways that modulate peripheral insulin action (Chawla et al. 2011). By utilizing in vitro models, these parts of processes and event cascades can be studied one by one to obtain new information on the roles of each event on the disease development such as type 2 diabetes and metabolic syndrome.

The successful construction of these models allowed the study of the impact of macrophages on hASC differentiation and adipocyte function. The presence of macrophages was found to induce larger lipid storage formation in adipocytes than adipocytes grown without macrophages had. Hence, interaction between macrophages and adipocytes/maturing adipocytes may be causing the formation of hypertrophic adipocytes in the obese individuals. This is in line with the previous studies which report that oxidative stress suppresses SREBF1, which is important in adipocyte differentiation (Okuno et al. 2018). Further studies would be needed to confirm the mechanisms by which this interaction leads to favoring the over expansion of 
adipocytes rather than adipogenesis of adipose stem cells.

The secretion of Adiponectin, IGF, PAI, and Leptin were increased in Adipocyte-Macrophage model with IFN $\gamma$ (AMMI) compared to model lacking macrophages. Production of adiponectin reverses insulin resistance associated with both lipoatrophy and obesity (Yamauchi et al. 2001). Hence, the model still shows signs of insulin sensitivity, although we found lipid accumulation to increase in the presence of macrophages. Change in expression of adiponectin has been shown to be a marker of insulin sensitivity independent from body mass index (Matulewicz et al. 2017). The expression of adiponectin also indicates that hyperplasia instead of hypertrophy is depicted in the model. Hyperplasia has been characterized as increased production of adiponectin and down regulation of inflammatory adipokines, whereas in hypertrophy adiponectin is down regulated and inflammatory adipokine production increased (Torres-Leal et al. 2012). Hypertrophic adipocytes lose their ability to store fat and increase their lipolytic activity. This process allows an increase in free fatty acid plasma concentration that in turn may impair the function of non-adipose organs, a process called lipotoxicity (DeFronzo 2004). It has been shown that hypertrophic adipocytes impair insulin signaling in adipocytes and other organs through dysregulated secretion of adipocytokines, such as adiponectin (Maeda et al. 2002), TNF $\alpha$ (Uysal et al. 1997), IL-6 (Rotter et al. 2003), and resistin (Steppan et al. 2001). Consequently, the secretion of these proteins might indicate that the model could be modifiable to depict insulin resistant tissue. Due to the pro-inflammatory markers expressed by AMMI, it is likely that the model presents state of early obesity, still expressing adiponectin but also secreting the cytokines linked to hypertrophic adipose tissue.

The macrophage produced cytokines, TNF $\alpha$ and IL-6 (Coelho et al. 2013), were found to be secreted in the AMMI which indicates that the macrophages were active in the model. Although mature adipocytes secrete $\mathrm{TNF} \alpha$, macrophages in adipose tissue are the main source of the cytokines (Maury et al. 2009). In obese humans, serum TNF $\alpha$ concentration is elevated but can be reversed through weight loss (Dandona et al. 1998). In adipose tissue, TNF $\alpha$ reduces the expression and activities of PPAR- $\gamma$, lipoprotein lipase and Glut-4, and hence impacts adipocyte differentiation, glucose uptake and lipid storage (Imai et al. 2004; Zhang et al. 1996). TNFa inhibits PPAR $\gamma$ activity and consequently leads to suppression of adipocyte differentiation and several conditions including insulin resistance (Ye and Gimble 2011). The nuclear receptor PPAR $\gamma$ is a lipid sensor that promotes lipid accumulation through gene transcription. TNF $\alpha$ regulates PPAR $\gamma$ both at pre-translational and post-translational levels (Ye 2008).

From the other secreted proteins, PAI, IGF and leptin; PAI has been found to cause hypercoagulation (Singh et al. 2013). IGF has been shown to influence proliferation and differentiation of perivascular adipocytes as well as stimulate migration of endothelial cells and angiogenesis (Liu et al. 2015; NakaoHayashi et al. 1992; Shigematsu et al. 1999). Leptin is also involved in the proliferation and differentiation of preadipocytes but especially functions as hormone regulating energy balance suppressing food intake and thereby inducing weight loss (Halaas et al. 1995; Wagoner et al. 2006).

The ratio of macrophage subtypes has been shown to differ between lean and obese mice (Weisberg et al. 2003). Obese adipose tissue macrophages express general macrophage marker cd68 and CD11b, CD11c, CD86, CD32, CCR7 (Thomas and Apovian 2017). As the isolated macrophages were positive for CD11b and CD68 they correlate with the previously reported adipose tissue macrophage marker expression. Obesity induces the accumulation of M1 macrophages to adipose tissue. M1 macrophages express IL-6, NOS, CCR2 (Lumeng et al. 2007) and $\mathrm{TNF} \alpha$, leading to a pro-inflammatory environment in adipose tissue (Ota 2013). Secretion of IL-6 was observed also in our model. Elevated plasma concentration of IL-6 is a marker for development of type 2 diabetes and for myocardial infarction (Pradhan et al. 2001; Ridker et al. 2000).

Both human serum (Andreesen et al. 1983; Musson 1983) and IFN $\gamma$ have been used to differentiate monocytes into macrophages in vitro (Ralph et al. 1983). M1 macrophages are the subset that is activated by IFN $\gamma$ (Murray and Wynn 2011). M1 macrophages express pro-inflammatory cytokines and inducible nitric-oxide synthase (Murray and Wynn 2011) and show high microbicidal activity and produce reactive oxygen species (Gordon and Taylor 2005).

In our results, the vasculature seemed to attenuate the effects caused by macrophages. However, the lipid 
accumulation was greater both with and without vasculature. The secretion of IL-8 and IP-10 (CXCL10) in VATMI indicates that the macrophages in the model are active. IP-10 has been shown to inhibit endothelial tubule formation (Bodnar et al. 2006). Although IP-10 was detected in VATMI it did not effect the formation of vascular network. It has been previously shown that expansion of adipose tissue vasculature counteracts obesity related inflammation and metabolic complications (Robciuc et al. 2016). This was seen in the decrease of TNFa, among other factors (Robciuc et al. 2016). Our results could indicate similar effect of vasculature on G-CSF, GMCSF, IL-1a and Rantes expression but further studies would be needed to confirm such effect. Rodciuc et al. found that the expansion of vasculature in adipose tissue had no effect on body weight (Robciuc et al. 2016). Hence, the increased lipid accumulation seems to be influenced by the macrophages independently rather than from the amount of vasculature.

Mature adipocytes could be utilized the assay to ensure the maturity of the adipocytes. Earlier studies have shown that the in vitro differentiation of pre adipocytes might be resulting in less mature adipocytes (Volz et al. 2019). The maintenance and longterm culture of mature adipocytes has been shown to be successful by others (Harms et al. 2019; Louis et al. 2019). In the future this in vitro protocol could be carried out with mature adipocytes. However, at the moment our goal is to also look into the differentiation of preadipocytes in the presence of inflammatory components. This research of differentiation process and its interactions with immune cells and inflammation markers would allow research of type 2 diabetes and other complications seen in context with obesity. The maturity of the adipocytes obtained after this culture period will be further studied in the future.

Limitation of this study is that the results have been obtained with cells from one adipose tissue sample. At this method development stage there were a lot of variables with multiple cell types and their growth requirements to consider. Hence, by using one adipose tissue sample we were able to compare the different protocols. The results obtained at this stage of the model development can only show trends of the changes. Also, it would be interesting, but we cannot discuss on the effects of the source of the sample on the results obtained at this stage of the study. For such comparison we would need wider ethical permits to collect more patient data and the study needs to be conducted with multiple different patient samples to obtain reliable data on such comparison. As presented in this study, we now have a ready protocol for the future experiments and these will include comparison of results obtained from different patient sample types to see whether the biology of the cells in adipose tissue is different depending on the source, whether we can see the difference in in vitro and if we can determine the different mechanism behind these differences in obese vs. normal weight, healthy and diabetic patient.

Here the protocols are presented at proof-ofconcept state and more extensive analyses will be conducted in the future. The protocols need further characterization to ensure their in vivo likeness. Monocytes/macrophages are not only immune cells present in the adipose tissue especially during the inflammation of the adipose tissue. Hence, the addition of other immune cell types should be investigated. The known and defined components and natural components used in the protocols make these kinds of changes easier than with the use of chemicals not found in vivo. For personalized medicine purposes, the amount of adipose tissue required for the model might be limiting factor in some cases.

\section{Conclusion}

As the number of obese individuals continues to rise, adipose tissue research is ever more important. Adipose tissue research needs new relevant and reliable tools for various research areas related to the tissue: studies of disease development, roles of tissue components on the disease onset and progression, toxicological studies and development of new treatments. By increasing the knowledge of the mechanisms behind the diseases such as type 2 diabetes and metabolic syndrome, the development of new treatment options is easier.

Human adipose tissue is an excellent and ample source of cells suitable for use in in vitro models aiming to depict human tissues. hASC are especially suitable cell type for in vitro adipose tissue models. The human cell in vitro model developed here, Vascularized adipose tissue model with macrophages, is a valuable tool for investigating the role of inflammation cytokines, immune cells and vascularization in human obesity. As the presence of 
macrophages seems to be affecting the lipid accumulation characteristics of adipocytes, it should be studied further. The presence of vascularization seemed to attenuate the changes in protein secretions. This could lead to more relevant intervention methods for the obesity related diseases related to inflammation and vascular changes.

The in vitro model presented here is especially relevant for the personalized medicine approaches. Personalized in vitro models enable studies of individual disease variants. Hence, the in vitro models utilizing one patient material would be especially important for disease studies in the rare disease types. Further efforts are still needed to fully utilize these new research tools in research as well as in drug development and diagnostic applications.

Acknowledgements We thank the patients and treating staff of Tampere university hospital for donating the tissue samples. We also like to acknowledge SPR for providing the blood samples and for the help with the cell isolation methods related to those samples. We like to acknowledge Ms. Sari Leinonen, Ms. Tuula Järvinen, Ms. Mirja Hyppönen, Ms. Hilkka Mäkinen, Ms. Paula Helpiölä and Ms. Maaret Vaani for the excellent and pedant technical assistance they provided. We would like to express our gratitude to The Diabetes Research Foundation for providing funding for this research.

\section{Compliance with ethical standards}

Conflicts of Interest TY and JR.S. have ATE patent issued in USA (US9056084B2) and Brazil (BRPI0918851A2), pending elsewhere (WO2010026299A1). Other authors declare no conflict of interest. The funders had no role in the design of the study; in the collection, analyses, or interpretation of data; in the writing of the manuscript, or in the decision to publish the results.

Open Access This article is licensed under a Creative Commons Attribution 4.0 International License, which permits use, sharing, adaptation, distribution and reproduction in any medium or format, as long as you give appropriate credit to the original author(s) and the source, provide a link to the Creative Commons licence, and indicate if changes were made. The images or other third party material in this article are included in the article's Creative Commons licence, unless indicated otherwise in a credit line to the material. If material is not included in the article's Creative Commons licence and your intended use is not permitted by statutory regulation or exceeds the permitted use, you will need to obtain permission directly from the copyright holder. To view a copy of this licence, visit http://creativecommons.org/licenses/by/4.0/.

\section{References}

Andreesen R, Picht J, Lohr GW (1983) Primary cultures of human blood-born macrophages grown on hydrophobic teflon membranes. J Immunol Methods 56:295-304

Bodnar RJ, Yates CC, Wells A (2006) IP-10 blocks vascular endothelial growth factor-induced endothelial cell motility and tube formation via inhibition of calpain. Circ Res 98:617-625

Chawla A, Nguyen KD, Goh YP (2011) Macrophage-mediated inflammation in metabolic disease. Nat Rev Immunol 11:738-749

Codoner-Franch P, Valls-Belles V, Arilla-Codoner A, AlonsoIglesias E (2011) Oxidant mechanisms in childhood obesity: the link between inflammation and oxidative stress. Transl Res 158:369-384

Coelho M, Oliveira T, Fernandes R (2013) Biochemistry of adipose tissue: an endocrine organ. Arch Med Sci 9:191-200

Dandona P, Weinstock R, Thusu K, Abdel-Rahman E, Aljada A, Wadden T (1998) Tumor necrosis factor-alpha in sera of obese patients: fall with weight loss. J Clin Endocrinol Metab 83:2907-2910

DeFronzo RA (2004) Dysfunctional fat cells, lipotoxicity and type 2 diabetes. Int J Clin Pract Suppl 143:9-21

Dominici M, Le Blanc K, Mueller I, Slaper-Cortenbach I, Marini F, Krause D, Deans R, Keating A, Prockop D, Horwitz E (2006) Minimal criteria for defining multipotent mesenchymal stromal cells. The International Society for Cellular Therapy position statement. Cytotherapy 8:315-317

Eljaafari A, Robert M, Chehimi M, Chanon S, Durand C, Vial G, Bendridi N, Madec AM, Disse E, Laville M, Rieusset J, Lefai E, Vidal H, Pirola L (2015) Adipose tissue-derived stem cells from obese subjects contribute to inflammation and reduced insulin response in adipocytes through differential regulation of the Th1/Th17 balance and monocyte activation. Diabetes 64:2477-2488

European Commission (2010) Sixth Report from the Commission to the Council and the European Parliament on the Statistics on the Number of Animals Used for Experimental and Other Scientific Purposes in the Member States of the European Union COM2010

Gil A, Maria Aguilera C, Gil-Campos M, Canete R (2007) Altered signalling and gene expression associated with the immune system and the inflammatory response in obesity. Br J Nutr 98(Suppl 1):S121-S126

Gordon S, Taylor PR (2005) Monocyte and macrophage heterogeneity. Nat Rev Immunol 5:953-964

Hackam DG, Redelmeier DA (2006) Translation of research evidence from animals to humans. JAMA 296:1731-1732

Haczeyni F, Bell-Anderson KS, Farrell GC (2018) Causes and mechanisms of adipocyte enlargement and adipose expansion. Obes Rev 19:406-420

Halaas JL, Gajiwala KS, Maffei M, Cohen SL, Chait BT, Rabinowitz D, Lallone RL, Burley SK, Friedman JM (1995) Weight-reducing effects of the plasma protein encoded by the obese gene. Science 269:543-546

Harms MJ, Li Q, Lee S, Zhang C, Kull B, Hallen S, Thorell A, Alexandersson I, Hagberg CE, Peng XR, Mardinoglu A, 
Spalding KL, Boucher J (2019) Mature human white adipocytes cultured under membranes maintain identity, function, and can transdifferentiate into brown-like Adipocytes. Cell Rep 27:213-225

Hotamisligil GS, Shargill NS, Spiegelman BM (1993) Adipose expression of tumor necrosis factor-alpha: direct role in obesity-linked insulin resistance. Science 259:87-91

Hotamisligil GS, Johnson RS, Distel RJ, Ellis R, Papaioannou VE, Spiegelman BM (1996) Uncoupling of obesity from insulin resistance through a targeted mutation in aP2, the adipocyte fatty acid binding protein. Science 274:1377-1379

Huttala O, Vuorenpaa H, Toimela T, Uotila J, Kuokkanen H, Ylikomi T, Sarkanen JR, Heinonen T (2015) Human vascular model with defined stimulation medium-a characterization study. Altex 32:125-136

Huttala O, Mysore R, Sarkanen JR, Heinonen T, Olkkonen VM, Ylikomi T (2016) Differentiation of human adipose stromal cells in vitro into insulin-sensitive adipocytes. Cell Tissue Res 366:63-74

Huttala O, Palmroth M, Hemminki P, Toimela T, Heinonen T, Ylikomi T, Sarkanen JR (2018) Development of Versatile Human In Vitro Vascularized Adipose Tissue Model with Serum-Free Angiogenesis and Natural Adipogenesis Induction. Basic Clin Pharmacol Toxicol 123:62-71

Imai T, Takakuwa R, Marchand S, Dentz E, Bornert JM, Messaddeq N, Wendling O, Mark M, Desvergne B, Wahli W, Chambon P, Metzger D (2004) Peroxisome proliferatoractivated receptor gamma is required in mature white and brown adipocytes for their survival in the mouse. Proc Natl Acad Sci USA 101:4543-4547

Kang JH, Gimble JM, Kaplan DL (2009) In vitro 3D model for human vascularized adipose tissue. Tissue Eng Part A 15:2227-2236

Kanneganti TD, Dixit VD (2012) Immunological complications of obesity. Nat Immunol 13:707-712

Kawai T, Seki M, Hiromatsu K, Eastcott JW, Watts GF, Sugai M, Smith DJ, Porcelli SA, Taubman MA (1999) Selective diapedesis of Th1 cells induced by endothelial cell RANTES. J Immunol 163:3269-3278

Kongsuphol P, Gupta S, Liu Y, Bhuvanendran Nair Gourikutty S, Biswas SK, Ramadan Q (2019) In vitro micro-physiological model of the inflamed human adipose tissue for immune-metabolic analysis in type II diabetes. Sci Rep 9:4887019

Li A, Dubey S, Varney ML, Dave BJ, Singh RK (2003) IL-8 directly enhanced endothelial cell survival, proliferation, and matrix metalloproteinases production and regulated angiogenesis. J Immunol 170:3369-3376

Liu P, Kong F, Wang J, Lu Q, Xu H, Qi T, Meng J (2015) Involvement of IGF-1 and MEOX2 in PI3K/Akt1/2 and ERK1/2 pathways mediated proliferation and differentiation of perivascular adipocytes. Exp Cell Res 331:82-96

Liu Y, Kongsuphol P, Chiam SY, Zhang QX, Gourikutty SBN, Saha S, Biswas SK, Ramadan Q (2019) Adipose-on-a-chip: a dynamic microphysiological in vitro model of the human adipose for immune-metabolic analysis in type II diabetes. Lab Chip 19:241-253

Lopez J, Huttala O, Sarkanen JR, Kaartinen I, Kuokkanen H, Ylikomi T (2016) Cytokine-rich adipose tissue extract production from water-assisted lipoaspirate: methodology for clinical use. Bioresour Open Access 5:269-278

Lopez JF, Sarkanen JR, Huttala O, Kaartinen IS, Kuokkanen HO, Ylikomi T (2018) Adipose tissue extract shows potential for wound healing: in vitro proliferation and migration of cell types contributing to wound healing in the presence of adipose tissue preparation and platelet rich plasma. Cytotechnology 70:1193-1204

Louis F, Kitano S, Mano JF, Matsusaki M (2019) 3D collagen microfibers stimulate the functionality of preadipocytes and maintain the phenotype of mature adipocytes for long term cultures. Acta Biomater 84:194-207

Lumeng CN, Deyoung SM, Saltiel AR (2007) Macrophages block insulin action in adipocytes by altering expression of signaling and glucose transport proteins. Am J Physiol Endocrinol Metab 292:E166-E174

Maeda N, Shimomura I, Kishida K, Nishizawa H, Matsuda M, Nagaretani H, Furuyama N, Kondo H, Takahashi M, Arita Y, Komuro R, Ouchi N, Kihara S, Tochino Y, Okutomi K, Horie M, Takeda S, Aoyama T, Funahashi T, Matsuzawa Y (2002) Diet-induced insulin resistance in mice lacking adiponectin/ACRP30. Nat Med 8:731-737

Makki K, Froguel P, Wolowczuk I (2013) Adipose tissue in obesity-related inflammation and insulin resistance: cells, cytokines, and chemokines. ISRN Inflamm 2013:139239

Marcu R, Choi YJ, Xue J, Fortin CL, Wang Y, Nagao RJ, Xu J, MacDonald JW, Bammler TK, Murry CE, Muczynski K, Stevens KR, Himmelfarb J, Schwartz SM, Zheng Y (2018) Human organ-specific endothelial cell heterogeneity. iScience 4:20-35

Mariotti M, Castiglioni S, Bernardini D, Maier JA (2006) Interleukin 1 alpha is a marker of endothelial cellular senescent. Immun Ageing 3:4

Matulewicz N, Stefanowicz M, Nikolajuk A, KarczewskaKupczewska M (2017) Markers of adipogenesis, but not inflammation, in adipose tissue are independently related to insulin sensitivity. J Clin Endocrinol Metab 102:3040-3049

Maury E, Noel L, Detry R, Brichard SM (2009) In vitro hyperresponsiveness to tumor necrosis factor-alpha contributes to adipokine dysregulation in omental adipocytes of obese subjects. J Clin Endocrinol Metab 94:1393-1400

Merfeld-Clauss S, Gollahalli N, March KL, Traktuev DO (2010) Adipose tissue progenitor cells directly interact with endothelial cells to induce vascular network formation. Tissue Eng Part A 16:2953-2966

Mitka M (2011) Drug for severe sepsis is withdrawn from market, fails to reduce mortality. JAMA 306:2439-2440

Murano I, Barbatelli G, Parisani V, Latini C, Muzzonigro G, Castellucci M, Cinti S (2008) Dead adipocytes, detected as crown-like structures, are prevalent in visceral fat depots of genetically obese mice. J Lipid Res 49:1562-1568

Murray PJ, Wynn TA (2011) Protective and pathogenic functions of macrophage subsets. Nat Rev Immunol 11:723-737

Musson RA (1983) Human serum induces maturation of human monocytes in vitro. Changes in cytolytic activity, intracellular lysosomal enzymes, and nonspecific esterase activity. Am J Pathol 111:331-340

Nakao-Hayashi J, Ito H, Kanayasu T, Morita I, Murota S (1992) Stimulatory effects of insulin and insulin-like growth 
factor I on migration and tube formation by vascular endothelial cells. Atherosclerosis 92:141-149

Nosalski R, Guzik TJ (2017) Perivascular adipose tissue inflammation in vascular disease. $\mathrm{Br} \mathrm{J}$ Pharmacol 174:3496-3513

Ojansivu M, Vanhatupa S, Bjorkvik L, Hakkanen H, Kellomaki M, Autio R, Ihalainen JA, Hupa L, Miettinen S (2015) Bioactive glass ions as strong enhancers of osteogenic differentiation in human adipose stem cells. Acta Biomater 21:190-203

Okuno Y, Fukuhara A, Hashimoto E, Kobayashi H, Kobayashi S, Otsuki M, Shimomura I (2018) Oxidative stress inhibits healthy adipose expansion through suppression of SREBF1-mediated lipogenic pathway. Diabetes 67:1113-1127

O'Rourke RW, White AE, Metcalf MD, Winters BR, Diggs BS, Zhu X, Marks DL (2012) Systemic inflammation and insulin sensitivity in obese IFN-gamma knockout mice. Metabolism 61:1152-1161

Ota T (2013) CCR5: a novel player in the adipose tissue inflammation and insulin resistance? Adipocyte 2:99-103

Patrikoski M, Juntunen M, Boucher S, Campbell A, Vemuri MC, Mannerstrom B, Miettinen S (2013) Development of fully defined xeno-free culture system for the preparation and propagation of cell therapy-compliant human adipose stem cells. Stem Cell Res Ther 4:27

Patti ME, Corvera S (2010) The role of mitochondria in the pathogenesis of type 2 diabetes. Endocr Rev 31:364-395

Pradhan AD, Manson JE, Rifai N, Buring JE, Ridker PM (2001) C-reactive protein, interleukin 6 , and risk of developing type 2 diabetes mellitus. JAMA 286:327-334

Ralph P, Harris PE, Punjabi CJ, Welte K, Litcofsky PB, Ho MK, Rubin BY, Moore MA, Springer TA (1983) Lymphokine inducing "terminal differentiation" of the human monoblast leukemia line U937: a role for gamma interferon. Blood 62:1169-1175

Ridker PM, Rifai N, Stampfer MJ, Hennekens CH (2000) Plasma concentration of interleukin- 6 and the risk of future myocardial infarction among apparently healthy men. Circulation 101:1767-1772

Robciuc MR, Kivela R, Williams IM, de Boer JF, van Dijk TH, Elamaa H, Tigistu-Sahle F, Molotkov D, Leppanen VM, Kakela R, Eklund L, Wasserman DH, Groen AK, Alitalo K (2016) VEGFB/VEGFR1-induced expansion of adipose vasculature counteracts obesity and related metabolic complications. Cell Metab 23:712-724

Rocha VZ, Folco EJ, Sukhova G, Shimizu K, Gotsman I, Vernon AH, Libby P (2008) Interferon-gamma, a Th1 cytokine, regulates fat inflammation: a role for adaptive immunity in obesity. Circ Res 103:467-476

Rotter V, Nagaev I, Smith U (2003) Interleukin-6 (IL-6) induces insulin resistance in 3T3-L1 adipocytes and is, like IL-8 and tumor necrosis factor-alpha, overexpressed in human fat cells from insulin-resistant subjects. J Biol Chem 278:45777-45784

Ruiz-Ojeda FJ, Ruperez AI, Gomez-Llorente C, Gil A, Aguilera CM (2016) Cell models and their application for studying adipogenic differentiation in relation to obesity: a review. Int J Mol Sci 17:1040

Sarkanen JR, Vuorenpaa H, Huttala O, Mannerstrom B, Kuokkanen $\mathrm{H}$, Miettinen S, Heinonen T, Ylikomi $\mathrm{T}$ (2012a) Adipose stromal cell tubule network model provides a versatile tool for vascular research and tissue engineering. Cells Tissues Organs 196:385-397

Sarkanen JR, Kaila V, Mannerstrom B, Raty S, Kuokkanen H, Miettinen S, Ylikomi T (2012b) Human adipose tissue extract induces angiogenesis and adipogenesis in vitro. Tissue Eng Part A 18:17-25

Seok J, Warren HS, Cuenca AG, Mindrinos MN, Baker HV, Xu W, Richards DR, McDonald-Smith GP, Gao H, Hennessy L, Finnerty CC, Lopez CM, Honari S, Moore EE, Minei JP, Cuschieri J, Bankey PE, Johnson JL, Sperry J, Nathens AB, Billiar TR, West MA, Jeschke MG, Klein MB, Gamelli RL, Gibran NS, Brownstein BH, Miller-Graziano C, Calvano SE, Mason PH, Cobb JP, Rahme LG, Lowry SF, Maier RV, Moldawer LL, Herndon DN, Davis RW, Xiao W, Tompkins RG, Inflammation and Host Response to Injury, Large Scale Collaborative Research Program (2013) Genomic responses in mouse models poorly mimic human inflammatory diseases. Proc Natl Acad Sci USA 110:3507-3512

Sheu WH, Ou HC, Chou FP, Lin TM, Yang CH (2006) Rosiglitazone inhibits endothelial proliferation and angiogenesis. Life Sci 78:1520-1528

Shigematsu S, Yamauchi K, Nakajima K, Iijima S, Aizawa T, Hashizume K (1999) IGF-1 regulates migration and angiogenesis of human endothelial cells. Endocr J 46(Suppl):S59-S62

Shulman GI (2000) Cellular mechanisms of insulin resistance. J Clin Invest 106:171-176

Singh NK, Gupta A, Behera DR, Dash D (2013) Elevated plasminogen activator inhibitor type-1 (PAI-1) as contributing factor in pathogenesis of hypercoagulable state in antiphospholipid syndrome. Rheumatol Int 33:2331-2336

Steppan CM, Bailey ST, Bhat S, Brown EJ, Banerjee RR, Wright CM, Patel HR, Ahima RS, Lazar MA (2001) The hormone resistin links obesity to diabetes. Nature 409:307-312

Switzer NJ, Mangat HS, Karmali S (2013) Current trends in obesity: body composition assessment, weight regulation, and emerging techniques in managing severe obesity. J Interv Gastroenterol 3:34-36

Thomas D, Apovian C (2017) Macrophage functions in lean and obese adipose tissue. Metabolism 72:120-143

Torres-Leal FL, Fonseca-Alaniz MH, de Oliveira AC, AlonsoVale MIC (2012) Adipose Tissue Inflammation and Insulin Resistance. InTech Open:137-156

US Department of Health and Human Services Food and Drug Administration, Center for Drug Evaluation and Research Guidance for Industry (2006) Nonclinical Safety Evaluation of Drug or Biologic Combinations

Uysal KT, Wiesbrock SM, Marino MW, Hotamisligil GS (1997) Protection from obesity-induced insulin resistance in mice lacking TNF-alpha function. Nature 389:610-614

van Baak MA (2013) Nutrition as a link between obesity and cardiovascular disease: how can we stop the obesity epidemic? Thromb Haemost 110:689-696

van der Worp HB, Howells DW, Sena ES, Porritt MJ, Rewell S, O'Collins V, Macleod MR (2010) Can animal models of disease reliably inform human studies? PLoS Med 7:e1000245 
Volz AC, Hack L, Atzinger FB, Kluger PJ (2018) Completely defined co-culture of adipogenic differentiated ASCs and microvascular endothelial cells. Altex 35:464-476

Volz AC, Omengo B, Gehrke S, Kluger PJ (2019) Comparing the use of differentiated adipose-derived stem cells and mature adipocytes to model adipose tissue in vitro. Differentiation 110:19-28

Vuornos K, Bjorninen M, Talvitie E, Paakinaho K, Kellomaki M, Huhtala H, Miettinen S, Seppanen-Kaijansinkko R, Haimi S (2016) Human Adipose Stem Cells Differentiated on Braided Polylactide Scaffolds Is a Potential Approach for Tendon Tissue Engineering. Tissue Eng Part A 22:513-523

Wagoner B, Hausman DB, Harris RB (2006) Direct and indirect effects of leptin on preadipocyte proliferation and differentiation. Am J Physiol Regul Integr Comp Physiol 290:R1557-R1564

Weisberg SP, McCann D, Desai M, Rosenbaum M, Leibel RL, Ferrante AW Jr (2003) Obesity is associated with macrophage accumulation in adipose tissue. J Clin Invest 112:1796-1808

Woodcock J, Woosley R (2008) The FDA critical path initiative and its influence on new drug development. Annu Rev Med 59:1-12
Yamauchi T, Kamon J, Waki H, Terauchi Y, Kubota N, Hara K, Mori Y, Ide T, Murakami K, Tsuboyama-Kasaoka N, Ezaki O, Akanuma Y, Gavrilova O, Vinson C, Reitman ML, Kagechika H, Shudo K, Yoda M, Nakano Y, Tobe K, Nagai R, Kimura S, Tomita M, Froguel P, Kadowaki T (2001) The fat-derived hormone adiponectin reverses insulin resistance associated with both lipoatrophy and obesity. Nat Med 7:941-946

Ye J (2008) Regulation of PPARgamma function by TNF-alpha. Biochem Biophys Res Commun 374:405-408

Ye J, Gimble JM (2011) Regulation of stem cell differentiation in adipose tissue by chronic inflammation. Clin Exp Pharmacol Physiol 38:872-878

Zhang B, Berger J, Zhou G, Elbrecht A, Biswas S, White-Carrington S, Szalkowski D, Moller DE (1996) Insulin- and mitogen-activated protein kinase-mediated phosphorylation and activation of peroxisome proliferator-activated receptor gamma. J Biol Chem 271:31771-31774

Publisher's Note Springer Nature remains neutral with regard to jurisdictional claims in published maps and institutional affiliations. 